\title{
A clinically functioning gonadotroph adenoma presenting with abdominal pain, bilateral multi-cystic ovaries \& fibromatosis
}

\section{Endocrinology department, North Bristol NHS Trust, 2. Neurosurgery department, North Bristol NHS Trust, 3. Gynaecology department, North Bristol NHS Trust}

\section{Introduction}

- We present the case of a clinically functioning gonadotroph adenoma in a pre-menopausal woman presenting with abdominal pain, multiple large ovarian cysts and fibromatosis

- To our knowledge, this is the first case of fibromatosis associated with a functioning gonadotroph adenoma

Case
- 35 y female
Three emergency admissions with abdominal pain:
$\quad 2^{\text {nd }}$ - right oophorectomy for large benign follicular cysts
cyst aspiration
$\quad \begin{aligned} & \text { 3rd - resection of a } 4 \times 1.7 \mathrm{~cm} \text { rectus abdominis muscle mass. Histology } \\ & \text { confirmed fibromatosis (desmoid tumour) }\end{aligned}$
Endocrine clinic review
- Persistent abdominal pain
- Irregular periods
- No galactorrhoea
- No headaches

\section{Investigations}

- Pelvic ultrasound images are shown in figures 1 and 2

- Endocrine investigations are shown in table 1

- Pituitary MRI images are shown in figures 3 and 4

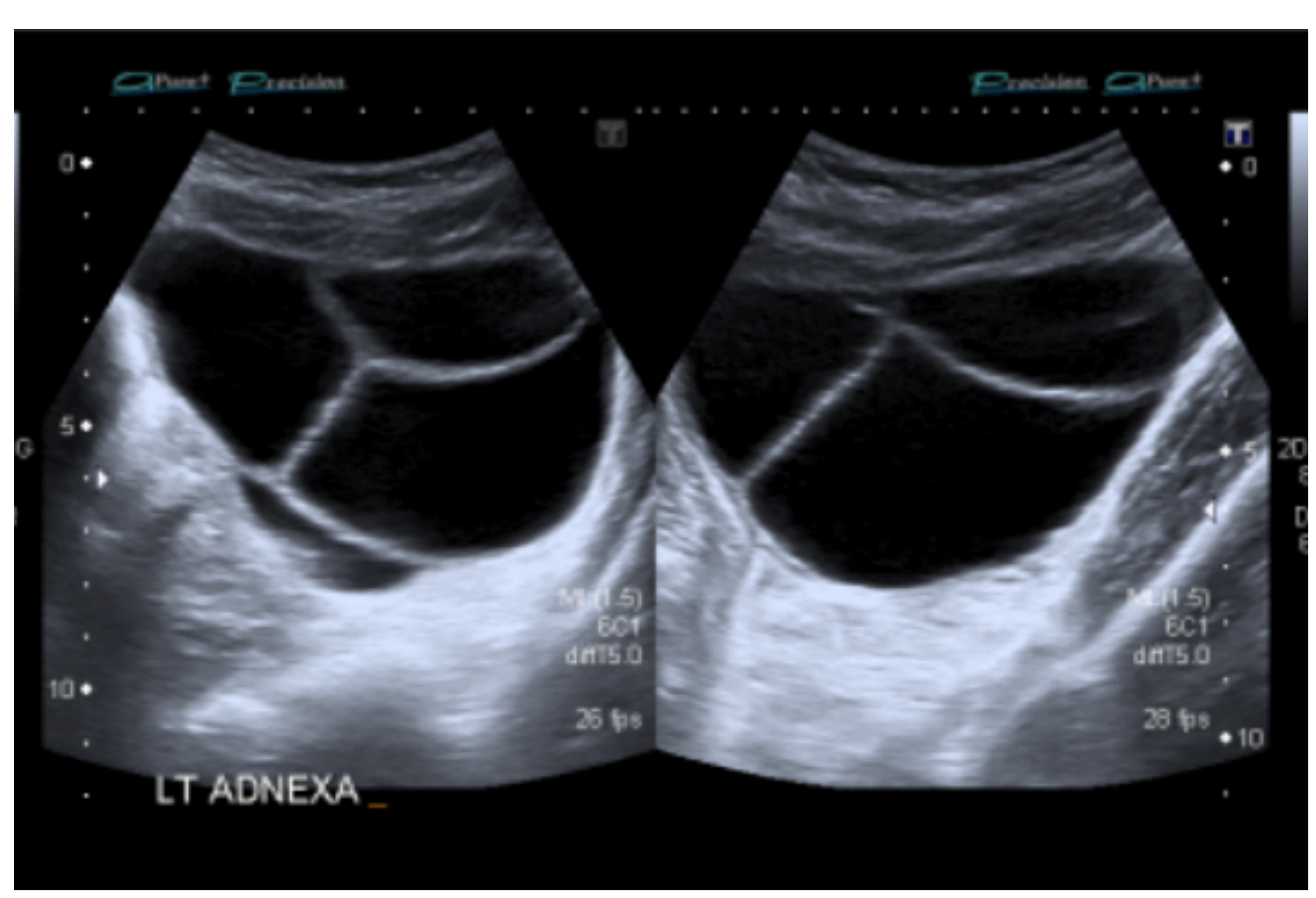

Figure 1

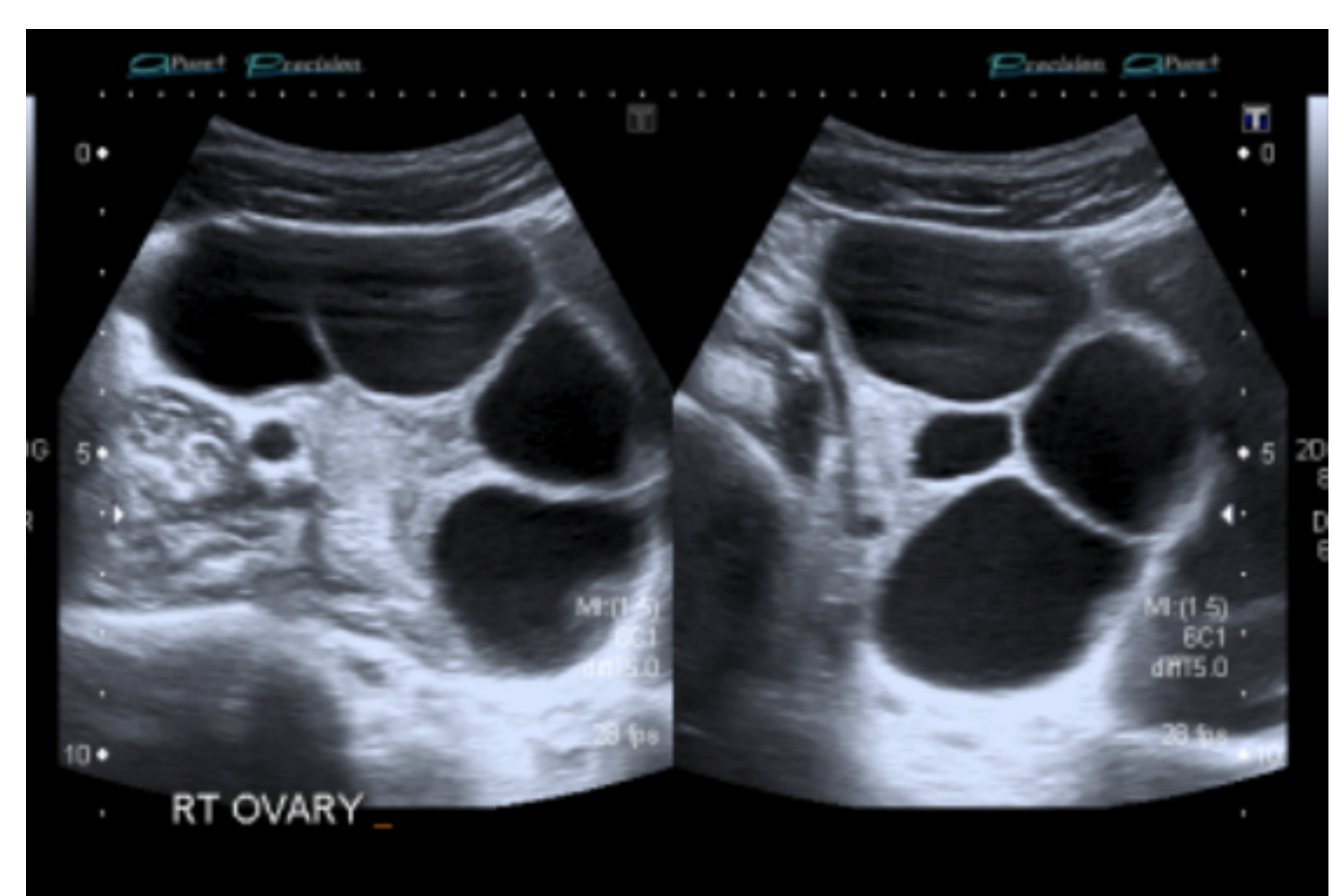

Figures 1\&2: Pelvic ultrasound demonstrating large, bilateral ovarian cysts

Figure 3: Pre-operative MRI pituitary showing a $1.5 \mathrm{~cm}$, right sided pituitary mass

Figure 4: Post-operative MRI pituitary showing resection of the gonadotroph adenoma

\section{Post-operatively}

- Abdominal pain resolved and normal menstrual cycle returned

- Oestradiol, FSH and LH levels normalised

- Pelvic ultrasound showed two normal follicles, $2-3 \mathrm{~cm}$ in size

- MRI pituitary 3 months post-operatively, showed removal of the pituitary tumour

\begin{tabular}{|c|c|c|c|}
\hline & \multicolumn{2}{|c|}{ Pre-operative } & \multirow{2}{*}{$\begin{array}{c}\text { Post-operative } \\
27 / 11 / 2017\end{array}$} \\
\hline & $12 / 5 / 2017$ & $26 / 5 / 2017$ & \\
\hline $\begin{array}{l}\text { Oestradiol (pmol/L) } \\
\text { FP <571 } \\
\text { LP 122-1094 }\end{array}$ & 2096 & 1111 & $<100$ \\
\hline $\begin{array}{l}\text { FSH (IU/L) } \\
\text { FP \& LP 1-9 }\end{array}$ & 8.7 & 9.0 & 3.2 \\
\hline $\begin{array}{l}\text { LH }(I U / L) \\
\text { FP 3.2-8.0 } \\
2.4-7.2\end{array}$ & 0.8 & 0.7 & 1.8 \\
\hline $\begin{array}{l}\text { Prolactin }(\mathrm{mlU} / \mathrm{L}) \\
<700\end{array}$ & 740 & & 191 \\
\hline $\begin{array}{l}\text { Testosterone }(\mathrm{nmol} / \mathrm{L}) \\
0.2-1.7\end{array}$ & $<0.3$ & & \\
\hline $\begin{array}{l}\text { Free T4 (pmol/L) } \\
12-22\end{array}$ & 19.9 & & 21.5 \\
\hline $\begin{array}{l}\mathrm{TSH}(\mathrm{mlU} / \mathrm{L}) \\
0.27-4.2\end{array}$ & 1.07 & & 0.60 \\
\hline Cortisol (nmol/L) & 396 & & 428 \\
\hline $\begin{array}{l}\text { IGF1 (nmol/L) } \\
7.4-31.3\end{array}$ & 17 & & \\
\hline
\end{tabular}

Table 1: Endocrine investigations (FP = follicular phase; $L P=$ luteal phase)

\section{Diagnosis \& management}

- A diagnosis of an FSH secreting pituitary adenoma was made

- The patient underwent transphenoidal hypophysectomy

- Histology confirmed a pituitary adenoma with FSH immunopositivity in keeping with gonadotroph cell adenoma
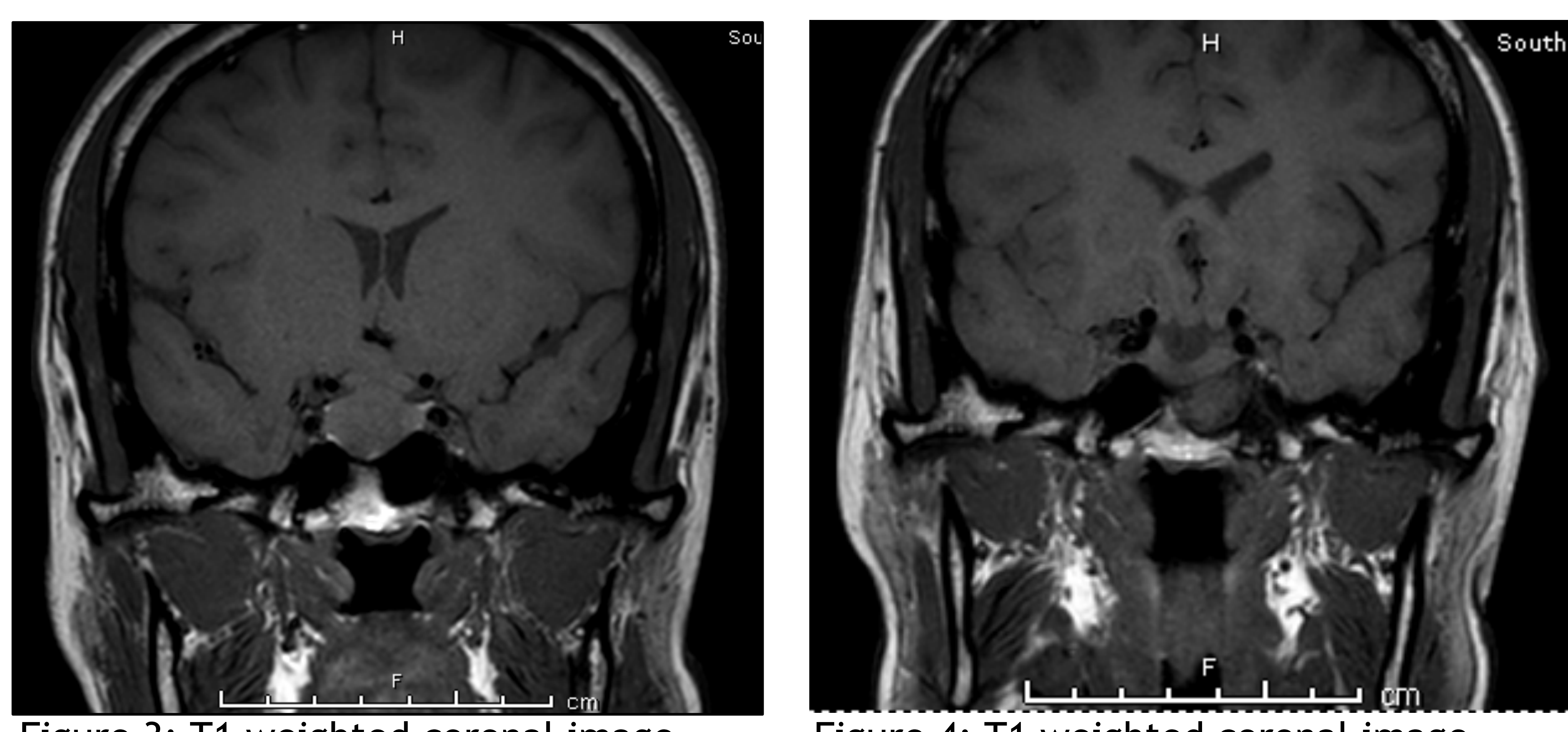

Figure 3: T1 weighted coronal image

Figure 4: T1 weighted coronal image

\section{Discussion}

- Gonadotroph adenomas are usually clinically non-functioning, but in rare cases can cause symptoms secondary to hormone hypersecretion. More commonly, gonadotroph

adenomas present with symptoms secondary to mass effect or are discovered incidentally.

- The prevalence of clinically functioning gonadotroph adenomas is not known, but there are only about 30 reported cases in the literature(1).

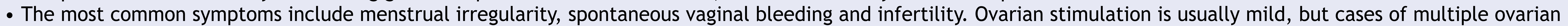
cysts leading to ovarian torsion have been reported(2).

- Fibromatosis (desmoid tumours) are rare tumours that are locally aggressive but do not have metastatic potential(3). They have been associated with high levels of oestrogen, for example in women during or following pregnancy. However, evidence for this association is limited to retrospective cases(4).

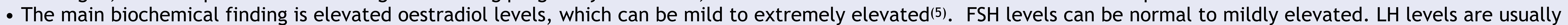
suppressed.

- Pituitary MRI reveals a macroadenoma in the majority of cases(5).

- Transphenoidal surgery is recommended as first line treatment for clinically functioning gonadotroph adenomas.

- Medical treatments have been used in individual cases with inconsistent results(5).

- There is limited data on long term outcomes, however long term follow up is required due to risk of recurrence.

\section{References}

1) Ezzat S, Asa S, Couldwell W, Barr C, Dodge W, Vance M; McCutcheon I. The prevalence of pituitary adenomas. Cancer $2004101613-9$.

2) Sicilia V, Earle J, Mezitis SG. Multiple ovarian cysts and oligomenorrhoea as the initial manifestation of a gonadotropin secreting pituitary macroadenoma.

Endocr Pract. 200612 417-42.

3) Reitamo JJ, Häyry P, Nykyri E, Saxén E. The desmoid tumor. I. Incidence, sex-, age- and anatomical distribution in the Finnish population. Am J Clin Pathol Reitamo JJ, Hayr

198277 665.

4) Lewis JJ, Boland PJ, Leung DH, Woodruff JM, Brennan MF. The enigma of desmoid tumors. Ann Surg $1999229866-1969$.
5) Ntali G, Capatina C, Grossman A, Karavitaki N. Functioning gonadotroph adenomas. JCEM 201499 4423-4433. 